\section{Effective utilization and maintenance of ICT facilities for quality teaching and learning outcome in secondary schools in Ondo State, Nigeria}

\author{
Ayeni, Adeolu Joshua $\bowtie$ \\ Deputy Director of Education, Ondo State Quality Education Assurance Agency, Akure, Ondo State, Nigeria \\ (ayeniadeolu@yahoo.com) \\ Ogunbameru, Mercy \\ Department of Business Education, Adeyemi College of Education, Ondo State, Nigeria \\ (ogunbamerumercy@yahoo.com)
}

Received: 8 January 2013

Revised: 10 June 2013 DOI: $10.5861 /$ ijrset 2013.304

Accepted: 1 August 2013

\title{
Abstract
}

The study assessed the level of availability and utilization of Information and Communication Technology (ICT) facilities for the attainment of quality learning outcome in secondary schools in Ondo State, Nigeria. It also investigated teachers' and students' opinions on the constraints, and strategies which could enhance effective utilization and maintenance of ICT facilities. A survey research design was adopted and quantitative technique was used for data collection and analysis. A total of 404 participants comprised 60 teachers and 344 students completed the questionnaire titled "ICT Facilities Utilization and Maintenance Survey Questionnaire (ICTFUMSQ)" in 7 randomly sampled public secondary schools. The reliability coefficient of 0.72 was obtained, using Cronbach alpha. Four research questions and one hypothesis were formulated. The simple percentage was used to answer the research questions while Pearson correlation statistics was employed to test the hypothesis at $p<0.05$. The findings indicated that the most commonly used ICT facilities were computer set (46.7\%); printer (41.7\%); and bulletin board (31\%). The results also showed that the relationship between teachers and students on the utilization of ICT facilities was low ( $\mathrm{r}=0.045, p<0.05$ ). The major constraints identified included shortage of ICT facilities and low capacity of teachers, irregular power supply, inadequate technical support, poor funding and maintenance. The study concluded that the stakeholders in education sector should collaborate to strengthen the institutional capacity in the provision of ICT facilities, and building teachers' and students' capacities for effective utilization and maintenance of ICT facilities to achieve better learning outcome in secondary schools.

Keywords: ICT facilities; ICT facilities utilization; ICT facilities maintenance; instructional process; learning outcome 


\section{Effective utilization and maintenance of ICT facilities for quality teaching and learning outcome in secondary schools in Ondo State, Nigeria}

\section{Introduction}

Teaching and learning is an organized instructional process that is consciously geared towards transforming and developing learners' intellectual ability, skills, ethics and values to enable them function effectively and become self-reliant, and contribute positively to societal development. Ede (2009) views teaching as a means of learning where learning is active, intentional, and motivational and a social process of knowledge construction and meaning making. Learning process entails the initiation, modification and change of perceptual order through active engagement of learners in the learning activities (Nurmi \& Jaakkola, 2006). In the context of this study, teaching and learning is a joint description of teacher and learners' complimentary and interdependent classroom activities initiated and directed towards helping the learners to access knowledge, increase understanding, develop concepts and practice skills to achieve a set of learning objectives and specified standards within a formal school system.

Ogwo and Oranu (2006) view teaching as the science and art of assisting a person to learn. The science in teaching entails the use of acquired knowledge from natural and behavioral science to appreciate the circumstances and personality of a learner. The art of teaching involves the use of both creative and demonstrating skills in enhancing the delivery of instruction. Teaching in the context of this study is a process of creating technology-based learning environment that will engage students in learner-centered activities that enable them to think, collaborate, construct meaning, and acquire knowledge, skills and attitude to foster learning. Okoro (2002) defined learning as a process by which knowledge, skills, habits, facts, ideas and principles are acquired through study, instruction or experience. In the context of this study learning encompasses the way and means by which learners used ICT facilities to acquire new or modifying existing knowledge, behavior, skills, values or preferences to enable them improve their performances or reorganize their thinking as a result of their active, intentional, motivational involvement in the process of knowledge construction, meaning making, and attitude development in a school system.

In Nigeria, studies by the Federal Ministry of Education (2010) revealed that most teachers still lack the knowledge and skills to use ICT facilities for curriculum instruction; this has been attributed to reasons such as: inadequacy of ICT facilities for the teeming population of teachers and students who need them, other reasons are poor and inadequate infrastructural support such as erratic electricity power supply, poor internet services, low bandwidth and poor maintenance of ICT facilities among others. The resultant effect of these inadequacies is low capacity of teachers to deliver the curriculum which has been largely responsible for low learning achievement and production of poor quality outputs from secondary schools. This situation is worrisome and portends serious danger to the much desired technological breakthrough for socio-economic development of Ondo State in particular and Nigeria in general. Thus, the purpose of this study was to examine the adequacy, utilization and maintenance of ICT facilities for effective teaching and better learning outcome in secondary schools particularly in Ondo State which is the only state with a full-fledged autonomous Quality Education Assurance Agency in South-west, Nigeria. This study is significant in the teaching-learning process, as strong emphasis is being placed on the acquisition of knowledge and skill in ICT training in Nigerian secondary schools. It is also envisaged that the findings of the research will stimulate and sustain stakeholders' intervention in the provision of ICT facilities and capacity building to enhance the quality of secondary education. 


\section{Literature review}

\subsection{ICT Facilities and learning outcome}

The goals of secondary education in Nigeria are: 1) preparation of the individuals for useful living within the society; and 2) preparation of the individuals for higher education (Federal Republic of Nigeria, 2004); consequently, the curriculum being offered in Nigerian secondary schools are diversified to cater for individual needs, inspired excellence, inculcate critical thinking and promote the nurturing and expression of a diversity of talents (Federal Republic of Nigeria, 2004). Based on the pre-determined educational goals, quality teaching and learning encompasses how learning is organized and managed; what is the content of learning; what level of learning is achieved; what goes on in the learning environment; and what are the learning outcomes. These fundamental issues underscore the need for consistent innovation and improvement in the quality of information and communication technology facilities that are used for teaching-learning process in secondary schools. This will no doubt enhance desirable learning outcome and help students to function successfully in a communication and technology oriented society.

Learning outcome is the quality or worth of knowledge, skills and attitude and values acquired in cognitive, affective and psychomotor domains of education for necessary self-confidence, reliance, effective citizenship and responsiveness to responsibilities and challenges of life (Mishra, 2008). The Federal Ministry of Education (2011a) highlighted the indicators of quality learning outcome as the standard attained and demonstrated by students in cognitive achievement especially in certificate examinations, and in life coping skills (i.e. skill in teamwork, diligence, punctuality, creativity, and many others), and in manipulative skills. In the context of this study, quality learning outcome is limited to the level of credit passes achieved by the students in the Senior School Certificate Examinations conducted by the West African Examinations Council (WASSCE) and National Examination Council (NECO SSCE) which make them eligible for admission into tertiary institutions for further study or fit into the world of work as employees or owners of small business enterprises.

The Federal Ministry of Education (2011a) opined that quality learning outcome depends on the quality of teaching and learning inputs and the qualitative processing of the inputs, which among others include the use of ICT facilities for teaching and learning. ICT facilities are enablers (equipment or technology-based services) which are provided to ease the performance of certain tasks, operations, events or processes. Yusuf and Onamsanya (2004) identified Information and Communication Technology (ICT) as an essential teaching and learning facility, which has become a natural part of man's daily life. Thus, ICT use in education by staff (academic and non-academic) and students has become a necessity. The essence of ICT utilization is to ensure that individuals participate fully in contemporary life and educational process to effectively accomplish their daily tasks.

The American Library Association (1983) defined ICT as the application of computers and other technologies to the acquisition, organization, storage, retrieval and dissemination of information. According to Adeyemo (2010), ICT in education is the application of digital equipment to all aspects of teaching and learning; the use of ICT in education falls into four (4) major categories, which are: 1) knowledge construction and problem solving (through the internet, e-mail, CD-ROM, databases, video conferencing); 2) process skills; 3) aiding explanation of concepts; and 4) communication of ideas through power points, desktop publishing etc. The American Library Association (1983) also categorized ICT use in education into three (3) groups which are: 1) data processing using computer hardware and software; 2) information storage using storage media such as memory cards, flash drives, CD-ROM, cassette (audio and video and the like) as ancillary media in addition to computer central processing unit; and 3) telecommunication using electronic based equipment, tools, and services which facilitate the transfer or communication of information i.e. internet services such as e-mail, web browsing, scanning, file protocol transfer for downloading or uploading of information. 
Tella, Tella, Toyobo, Adika, and Adeyinka (2007) conducted a study among private secondary schools in Ibadan on teachers' uses of ICTs and the implication for further development of ICTs use in Nigerian secondary schools. The finding showed that $61 \%$ of teacher respondents had access to only computer in schools; $19 \%$ had access to video equipment; $10 \%$ had access to digital camera; no teacher indicated access to internet and e-mail; technical support and internet was grossly inadequate; teachers lack expertise in using ICT in teaching and learning while majority of the teachers agreed that the use of ICT makes lesson more interesting and fun.

Teachers are empowered through the use of ICT in teaching and learning processes to facilitate the development of complex skills that will keep them afloat and relevant in contemporary knowledge society. Yusuf (2004) asserted that ICT makes schools to be more efficient and productive, engendering varieties of tools to support and facilitate teachers' professional development. ICTs are seen as tools in teachers' hands to reform teaching and stimulate learners to learn actively and independently in a self-directed way and in collaboration with others.

The study conducted by Hussain, Iqbal, and Akhtar (2010) on public school in Islambad in Pakistan revealed that teaching through technology based learning environment enhanced the achievement level of the students. To create good schools with ICT resources will take substantial financial resource allocation from the national budget, spent more strategically, with strong political commitment of government to ensure equity and universal access to education. However, in the situation where the required infrastructure such as electricity and standard ICT Laboratory are not available, teachers are incapacitated in using computer to facilitate effective teaching and learning processes.

In a similar study conducted by the Federal Ministry of Education in Nigeria in 2003, only 37.67\% of public and private secondary schools sampled had access to computer facilities while there was acute shortage of qualified teachers for computer studies. Further investigation in 2008 revealed that less than $60 \%$ of public schools have access to ICT facilities and constrained by low capacity of teachers for ICT utilization and poor electricity supply (Federal Ministry of Education, 2009). This situation constitutes a serious gap in the teaching-learning process and perhaps been responsible for students' low academic achievement in secondary schools.

The trend in Nigerian students' academic performance has shown continuous low integration and impact of ICT facilities on academic achievement. For instance, the Federal Ministry of Education (2006) reported that students' academic performance in Senior Secondary School Certificate Examination (SSCE) conducted between 2000 and 2006 was below 50\%. Bello-Osagie and Olugbamila (2009) also reported that in the 2009 November/December Senior Secondary School Certificate Examination conducted by the National Examination Council (NECO-SSCE) out of the total number of 234,682 Nigerian candidates who sat for the examination, only 4,223 obtained credit passes and above in five subjects including English and Mathematics, which is a 98.2\% failure rate. Owadiae (2010) reported that in 2009 May/June Senior Secondary Certificate Examination conducted by the West African Examinations Council, only 25.99\% of the candidates obtained credit passes and above in five subjects including English Language and Mathematics, while in the 2010 May/June WASSCE, out of the 1,135,557 candidates that sat for the examination, only 337,071 (24.94\%) candidates obtained five credit level passes and above in subjects including English Language and Mathematics (Federal Ministry of Education, 2011b).

Furthermore, in Nigeria, the 2011 May/June Senior Secondary Certificate Examination conducted by West African Examinations Council shows that only 30.99\% of the 1,540,250 candidates obtained credit level passes and above in five subjects including English Language and Mathematics, while in 2012 May/June WASSCE, $649,156(38.81 \%)$ of the 1,672,224 candidates that sat for the examination obtained five credit level passes and above in subjects including English Language and Mathematics .in the 36 states of the Federation and the Federal Capital Territory (Owadiae, 2011, 2012).

In the same vein, in Ondo State, the percentage of students who obtained credit level passes in five subjects 
Effective utilization and maintenance of ICT for quality teaching and learning outcome in Nigeria

and above including English Language and Mathematics in secondary schools in the Senior School Certificate Examination conducted by the West African Examinations Council (WASSCE), between 2007 and 2009 ranged from $16.7 \%$ to $19.1 \%$, and $30.17 \%$ in 2010 , while $42 \%$ was recorded in 2012 . The National Examination Council result ranged from 3.2\% to 27\% between 2007 and 2009 (Ondo State Quality Education Assurance Agency, 2010; Ondo State Ministry of Education, 2012).

The study conducted by Ayeni (2010) on Ondo state secondary schools revealed that $54.2 \%$ of the schools lack well equipped computer laboratory. Consequently, many schools could not meet the ICT facilities required for effective curriculum delivery. This implied that only few secondary schools could achieve quality assurance in teaching and learning processes. This situation would no doubt cause students' low academic performance. Hence, the need to further examines the adequacy, utilization and maintenance of ICT facilities with a view to advising stakeholders in education sector to improve on the provision, capacity utilization and sustenance of ICT facilities in secondary schools.

\subsection{Relevance and sustenance of ICT facilities in instructional process}

Information and Communication Technologies (ICTs) are indispensable tools in transmission of knowledge and have been accepted as viable means of communication in the contemporary world. ICT facilities in this study are instructional equipment and services which make teaching and learning processes to be done electronically and provide access to a wide range of innovative, informative and educational materials on the internet in order to bring the world into the classroom. ICT is used for gathering, processing, storing, sharing and distributing information, knowledge and ideas (ESCAP in Ugwoke, 2011).

Adeyemo (2010) described ICT as consisting of computer hardware, software, networks and media for the collection, storage, processing, transmission and presentation of information. ICT in this study also includes computers sets, computer and application software (ie spreadsheet, word processing, excel), disc and storage media (i.e memory cards, flash drives, CD-ROMs, audio and video cassettes, films, picture, e-books, e-magazines) telecommunication gadget and services such as internet, internet browsing, electronic mail services, cyber café, scanner, browsers, internet services provider which are used in the secondary school for processing, storage, presentation, communication and exchange of data and information in the teaching and learning processes.

Effective utilization of ICT facility for instructional process reinforces the teacher's ability to cater for individual differences and fosters learners' involvement, participation and understanding, which help them in grounding their thoughts and feelings and in turns contribute to good academic performance in schools. In this new era, ICTs are recognized as means of quality assurance in curriculum management. For instance, the use of ICT to instruct students will help them learn better as they do not always forget what they are taught when used alongside the traditional method of teaching (Hussain, Iqbal, \& Akhtar, 2010).

ICT stands to improve teaching and learning, and secondary schools with very good ICT resources achieved, on the average, better results in English, Mathematics and Science than those with poor ICT resources (Becta, 2001). Internet usage for teaching and learning can assist the teachers to discover new methods and simple process of teaching, while the students can construct their own understanding and be in complete control of their topics through the sharing of ideas and experiences worldwide by accessing diverse collections of information from on-line journals, books, magazines, newspapers, and many others. The teachers are therefore, expected to give considerable attention to the selection and use of appropriate instructional resources to stimulate students' interest for meaningful learning during lessons. For instance, the use of interactive whiteboards, video projection units, microscopes connected to computers, prepared spreadsheets to capture and model data, provide more opportunities and add value to cuuriculum delivery (Hussain, Iqbal, \& Akhtar, 2010). Student learning activity and task engagement, higher order thinking skill, and flexibility in terms of time, learning environment and teacher-learner interaction have been reported to be enhanced by using ICT in learning. Effective uses of ICT 
Ayeni, A. J. \& Ogunbameru, M.

facilities promote high academic achievement as indicators of quality learning outcome (Yusuf, 2004).

Literature abounds with the benefits of ICT in education, Tella et. al (2007) highlighted the followings as the benefits of ICT to student learning: it improves learners motivation, facilitates the recall of previous learning, provides new instructional stimuli, activates the learners' response, provide systematic and steady feedback, facilitates appropriate practices, provide a viable source of information to enhance learning, development of desirable attitude towards learning in learners particularly lifelong learning, enables students to gain deeper understanding of complex topics and concepts to develop higher order thinking, facilitates creativity and research skills. It also serves as rich sources of information for student looking for ideas for project and assignment as well as enhances quality learning and better academic achievement for students when they are exposed to video-based instruction.

In the same vein, ICTs utilization in teaching and learning offer the following benefits: it enables teachers to implement and manage teaching and learning in flexible ways and in learners' friendly learning environments (Tella et. al, 2007). ICT empowers the teachers to prepare the current generation of students for future workplace, that is providing tools for tomorrow's practices (Yusuf \& Onansanya, 2004); Adeyemo (2010) asserted that jobs in today's markets require the use of technology, collaboration, teamwork, effective communication and other life coping skills which can be acquired through teaching and learning with ICT. Teachers are empowered through the use of ICT in teaching and learning processes to facilitate the development of complex skills that will keep them afloat and relevant in contemporary knowledge society. Furthermore, Yusuf (2004) asserted that ICT makes schools to be more efficient and productive, engendering varieties of tools to support and facilitate teachers' professional development. ICTs are seen as tools in teachers' hands to reform teaching to stimulate learners to learn actively and independently in a self-directed way and in collaboration with others.

In spite of the benefits of ICT in education, it has been established that most teachers have not taken these advantages in their classroom teaching and professional development. The various reasons adduced for low utilization of ICT facilities in teaching-learning process are inadequacy of ICT facilities for the teeming population of teachers and students who need them, others reasons are poor and inadequate infrastructural support such as erratic electricity supply, poor internet services, low bandwidth, poor maintenance of ICT facilities (Yusuf \& Onasanya, 2004; Tella et. al, 2007; Okoro, 2009; Adeyemo, 2010).

To maintain is to keep something in good working condition and in existence for continuous use. The maintenance of ICT facilities in the context of this study mean measures put in place to keep ICT facilities in continuous good working conditions. Such measures include capacity building program for technical staff on ICT maintenance, provision of alternative sources of electricity supply, increasing the time allocated for ICT training, instructions and practice, connectivity of school to the internet, school partnership with relevant professional and corporate bodies for technical support, periodic organization of workshops, seminars and conferences on ICT for teachers and students to improve their capacity in the usage of ICT facilities for teaching and learning in secondary schools.

\subsection{Statement of the Problem}

The major challenge facing the school system in Nigeria is how to improve the dwindling student learning outcome. The domain of education, particularly teaching and learning in Nigerian secondary school system has not been so influenced even when teachers claimed that they are aware of the benefits of using ICT in teaching and learning processes (Okoro, 2009; Olulube \& Ubogu, 2009; Adeyemo, 2010; Ugwoke, 2011). The inability of many teachers therefore to use ICT facilities in classroom teaching and learning may hinder critical thinking skills of the students in self-directed learning, teamwork, collaboration and effective communication.

The percentage of students' academic achievement in the Senior School Certificate Examination in public secondary schools is still relatively low (below $40 \%$ ), which reflects $38.73 \%$ in Ondo State and $38.81 \%$ in Nigeria as a whole (Ondo State Ministry of Education, 2012; Owadiae, 2012). Since ICT utilization is a factor 
promoting contemporary teaching and learning worldwide, this study was therefore designed to examine the adequacy and maintenance of ICT facilities, and assess the level of teachers' and students' utilization of ICT in teaching and learning processes in order to improve students' capacity towards better learning achievement in public secondary schools.

\subsection{Research questions}

The following research questions guided the study:

a. How adequate are ICT facilities available for instructional process in secondary schools in Ondo State?

b. What is the extent of utilization of ICT facilities in instructional process in secondary schools in Ondo State?

c. What are the problems that hinder effective utilization of ICT facilities in instructional process in secondary schools in Ondo State?

d. What are the strategies for enhancing the effective utilization of ICT facilities in instructional process in secondary schools in Ondo State?

\subsection{Research hypothesis}

$\mathrm{Ho}_{1}$ : There is no significant relationship in the perception of teachers and students on the extent of utilization of ICT facilities in instructional process in secondary schools in Ondo State.

\section{Methodology}

The study used a descriptive survey design, and combined quantitative and qualitative techniques for data collection and analysis. The target population for the study consisted of the entire principals, teachers and students in the 303 public secondary schools in Ondo State, South-west, Nigeria. Ondo Education Zone, which has the highest number of secondary schools out of the five educational zones (Akure, Ikare, Okitipupa, Ondo and Owo) in Ondo State, was used as case study. A total of 420 respondents (70 teachers and 350 students) constituted the sample size and were randomly sampled from seven (7) secondary schools randomly selected from 35 public secondary schools in Ondo West Local Government, which was purposively selected because it has the highest number of secondary schools out of the Four (4) Local Government Areas in Ondo Education Zone. The study was limited to public secondary schools in order to assess the government's direct impact on the provision of ICT facilities in meeting the challenges of teaching and learning for quality secondary education. Hence, the findings would not be generalized for the private secondary schools.

The instrument used for data collection was a 47 structured questionnaire developed by the researchers and titled 'ICT Facilities Utilization and Maintenance Questionnaire (ICTFUMQ); the instrument comprised two sections. The first, section A, had 21 items which sought information from the respondents on the availability of ICT facilities, while the second, section B, had 26 items; that sought relevant research information on the level of utilization of ICT facilities. The instrument utilized a 4- point rating scale indicating frequently utilized, moderately utilized, seldomly utilized, and never utilized with 4, 3, 2, and 1 point for rating ICT facilities utilization, while very adequate, adequate, slightly adequate, and inadequate, with $4,3,2$, and 1 rating points used to assess the level of maintenance of ICT facilities in secondary schools.

The instrument was validated using content and construct validity, while the items were further subjected to meticulous vetting and review by experts in the Department of Vocational Teacher Education, University of Nigeria, Nsukka; and Department of Educational Technology, and Test and Measurement in the Faculty of Education at Obafemi Awolowo University, Ile-Ife, which ascertained the suitability of the items on the 
Ayeni, A. J. \& Ogunbameru, M.

instrument. Thereafter, the instrument was pilot tested by using 22 teachers and 40 students in Okitipupa Education Zone to determine its reliability by Cronbach's Alpha which yielded reliability co-efficient of 0.72 , an indication of reasonable inter-item consistency. Finally, the instrument was administered through the help of two trained research assistants, while the researchers coordinated the administration and collation of completed questionnaires. Data collected were analyzed using frequency and simple per-cent for the research questions and Pearson correlation statistics for the hypothesis testing at $p<0.5$ level of significance; using Statistical Package for Social Sciences (SPSS) version 16.0.

\section{Results}

The results of data analysis were presented in order of research questions and hypothesis while the discussions of findings were carried out to examine ICT facilities as intervening variables in determining the quality of teaching and learning outcomes in secondary schools.

\subsection{How adequate are ICT Facilities available in secondary schools in Ondo State?}

The evidence from the data analysis presented in table 1 showed that secondary schools had ICT facilities very adequate in computer set $(46.7 \%)$, printer $(41.7 \%)$, and bulletin board (31\%); slightly adequate in computer set (30\%) and bulletin board (30\%); and inadequate in printer (35\%), scanner (54.2\%), internet (65.5\%), radio $(58.3 \%)$, projector $(56.7 \%)$, telephone $(56.7 \%)$, flash drive $(46.7 \%)$, CD-ROM $(54.2 \%)$, web communication technology (67.8\%), digital camera (51.7\%), and fax machine (75\%).

\section{Table 1}

Availability of ICT facilities in secondary schools

\begin{tabular}{lcccccc}
\hline \multirow{2}{*}{ Computer facilities } & \multicolumn{2}{c}{ Very adequate } & \multicolumn{2}{c}{ Fairly adequate } & \multicolumn{2}{c}{ Inadequate } \\
& Frequency & $\%$ & Frequency & $\%$ & Frequency & $\%$ \\
\hline Computer Set & 28 & 46.7 & 18 & 30.0 & 14 & 23.3 \\
Printer & 25 & 41.7 & 14 & 23.3 & 21 & 35.0 \\
Scanner & 17 & 28.8 & 10 & 15.9 & 32 & 54.2 \\
Bulletin board & 19 & 31.0 & 18 & 30.0 & 23 & 54.2 \\
Internet & 14 & 24.1 & 5 & 10.3 & 38 & 65.5 \\
Radio & 12 & 20.0 & 13 & 21.7 & 35 & 58.3 \\
Projector & 15 & 25.0 & 11 & 18.3 & 34 & 56.7 \\
Telephone & 15 & 25.0 & 11 & 18.3 & 34 & 56.7 \\
Flash drive & 18 & 30.0 & 14 & 23.3 & 32 & 54.2 \\
CD-Rom & 15 & 27.1 & 11 & 18.6 & 40 & 67.8 \\
Web communication technology & 12 & 20.3 & 7 & 11.9 & 40 & 67.8 \\
Digital camera & 5 & 10.0 & 17 & 28.3 & 37 & 51.7 \\
Fax machine & 8 & 13.3 & 7 & 11.7 & 45 & 75.0 \\
\hline
\end{tabular}

\subsection{What is the extent of ICT facilities utilization in instructional process in secondary schools?}

The data presented in table $2 \mathrm{a}$ and $2 \mathrm{~b}$ revealed that teachers' utilization of ICT facilities in Instructional process was very low as reflected in the following percentage points: frequently utilized $(1.7 \%-20.3 \%)$; moderately utilized ( $8.5 \%-29.3 \%)$; seldom utilized $(8.9 \%-31.7 \%)$; and never utilized $(31.7 \%-74.6 \%)$. The data presented in table 2.2 indicated that students' utilization of ICT facilities in learning process was very low as reflected in the following percentage points: frequently utilized (12.1\%- 26.9\%); moderately utilized (11.2\%-23.5\%); seldom utilized 8.1\%-19.7\%); and never utilized (38.9\% - 65.8\%). 
Effective utilization and maintenance of ICT for quality teaching and learning outcome in Nigeria

Table 2a

Teachers' utilization of ICT facilities in secondary schools

\begin{tabular}{lcccccccc}
\hline \multirow{2}{*}{ ICT facilities } & \multicolumn{2}{c}{ Frequently utilized } & \multicolumn{2}{c}{ Moderately utilized } & \multicolumn{2}{c}{ Seldom utilized } & \multicolumn{3}{c}{ Never utilized } \\
& Frequency & $\%$ & Frequency & $\%$ & Frequency & $\%$ & Frequency & $\%$ \\
\hline Computer set & 11 & 19.6 & 10 & 17.9 & 11 & 19.6 & 24 & 42.9 \\
Computer accessories & 9 & 15.1 & 17 & 28.3 & 15 & 25.0 & 19 & 31.7 \\
Printer & 12 & 20.3 & 11 & 18.6 & 17 & 28.8 & 19 & 32.2 \\
Scanner & 6 & 10.3 & 13 & 22.4 & 12 & 20.7 & 27 & 46.6 \\
Bulletin board & 7 & 11.7 & 11 & 18.3 & 19 & 31.7 & 23 & 38.3 \\
Internet technology & 4 & 6.7 & 12 & 20.0 & 9 & 15.0 & 35 & 58.3 \\
Radio & 5 & 8.3 & 6 & 10.0 & 10 & 16.7 & 39 & 65.0 \\
Email & 1 & 1.7 & 8 & 13.3 & 8 & 13.3 & 43 & 71.7 \\
Telephone & 8 & 13.3 & 8 & 13.3 & 6 & 10.0 & 38 & 63.3 \\
Video conferencing & 3 & 5.1 & 5 & 8.5 & 7 & 11.9 & 44 & 74.6 \\
Word processor & 4 & 6.9 & 17 & 29.3 & 7 & 12.1 & 30 & 51.7 \\
Web communication & 4 & 8.9 & 8 & 17.8 & 4 & 8.9 & 28 & 62.2 \\
Upload/download file & 5 & 9.4 & 14 & 25.4 & 7 & 13.2 & 27 & 50.9 \\
Digital camera & 1 & 1.7 & 7 & 11.7 & 8 & 13.3 & 44 & 73.3 \\
\hline
\end{tabular}

Table 2b

Students' utilization of ICT facilities in secondary schools

\begin{tabular}{|c|c|c|c|c|c|c|c|c|}
\hline \multirow{2}{*}{ ICT facilities } & \multicolumn{2}{|c|}{ Frequently utilized } & \multicolumn{2}{|c|}{ Moderately utilized } & \multicolumn{2}{|c|}{ Seldom utilized } & \multicolumn{2}{|c|}{ Never utilized } \\
\hline & Frequency & $\%$ & Frequency & $\%$ & Frequency & $\%$ & Frequency & $\%$ \\
\hline Computer set & 70 & 20.1 & 82 & 23.5 & 50 & 14.3 & 147 & 42.1 \\
\hline Computer accessories & 57 & 16.5 & 70 & 20.2 & 68 & 19.7 & 151 & 43.6 \\
\hline Printer & 94 & 26.9 & 76 & 21.7 & 42 & 12.1 & 135 & 38.9 \\
\hline Scanner & 53 & 15.1 & 58 & 16.9 & 63 & 18.3 & 170 & 49.4 \\
\hline Bulletin board & 46 & 13.7 & 66 & 19.6 & 40 & 11.9 & 184 & 54.8 \\
\hline Internet technology & 57 & 16.5 & 50 & 14.5 & 33 & 9.6 & 205 & 59.4 \\
\hline Radio & 66 & 18.9 & 39 & 11.2 & 50 & 14.3 & 194 & 55.6 \\
\hline Email & 50 & 14.6 & 53 & 15.5 & 29 & 8.5 & 210 & 61.4 \\
\hline Telephone & 63 & 18.2 & 60 & 17.3 & 38 & 11.0 & 185 & 53.5 \\
\hline Video conferencing & 41 & 12.1 & 36 & 10.6 & 60 & 17.6 & 203 & 59.7 \\
\hline Word processor & 47 & 13.7 & 58 & 16.9 & 60 & 17.5 & 178 & 51.9 \\
\hline Web communication & 49 & 14.3 & 58 & 17.0 & 41 & 12.0 & 194 & 56.7 \\
\hline Upload/download file & 45 & 12.9 & 80 & 23.1 & 28 & 8.1 & 194 & 55.9 \\
\hline Digital camera & 45 & 13.5 & 42 & 12.3 & 29 & 8.5 & 225 & 65.8 \\
\hline
\end{tabular}

4.3 What are the problems that hinder effective utilization of ICT facilities in instructional process in secondary schools?

The data presented in table 3 revealed that all the 13 items are factor constraints militating against effective use and maintenance of ICT facilities in secondary schools. Most teachers agreed that there are inadequate supply of computer hardware and software; irregular power supply; limited training opportunities for teachers; and low level of institutional partnership with professional and corporate bodies for technical support. 
Ayeni, A. J. \& Ogunbameru, M.

Table 3

Constraints to effective utilization of ICT facilities

\begin{tabular}{|c|c|c|c|c|c|c|c|c|}
\hline \multirow{2}{*}{ Issues } & \multicolumn{2}{|c|}{ Highly agree } & \multicolumn{2}{|c|}{ Agree } & \multicolumn{2}{|c|}{ Fairly agree } & \multicolumn{2}{|c|}{ Highly disagree } \\
\hline & $n$ & $\%$ & $n$ & $\%$ & $n$ & $\%$ & $n$ & $\%$ \\
\hline Inadequate supply of computer hardware & 15 & 27.3 & 20 & 36.4 & 14 & 25.5 & 5 & 10.9 \\
\hline Inadequate supply of computer software & 12 & 21.4 & 24 & 42.9 & 13 & 23.2 & 7 & 12.5 \\
\hline Irregular power supply & 17 & 29.8 & 21 & 35.8 & 9 & 15.8 & 10 & 17.5 \\
\hline Lack of training in the use of ICT facilities & 16 & 28.1 & 19 & 33.3 & 13 & 22.8 & 9 & 15.8 \\
\hline $\begin{array}{l}\text { Lack of institutional partnership with professional and } \\
\text { corporate bodies for technical support }\end{array}$ & 14 & 24.6 & 21 & 36.8 & 12 & 21.1 & 10 & 17.5 \\
\hline Malfunctioning of internet connectivity & 15 & 28.1 & 13 & 22.8 & 14 & 24.6 & 14 & 24.6 \\
\hline Poor service of internet providers & 18 & 31.6 & 15 & 26.3 & 11 & 19.3 & 13 & 22.8 \\
\hline Insufficient knowledge of how to use ICT & 12 & 21.4 & 16 & 28.6 & 15 & 26.8 & 13 & 23.2 \\
\hline Poor maintenance of computer hardware & 13 & 22.8 & 15 & 26.3 & 17 & 29.8 & 12 & 21.1 \\
\hline Poor maintenance culture in the school system & 11 & 19.3 & 15 & 28.1 & 15 & 28.1 & 14 & 24.6 \\
\hline Bureaucratic/administrative bottleneck in funding & 11 & 19.6 & 14 & 25.0 & 20 & 35.7 & 11 & 19.6 \\
\hline
\end{tabular}

4.4 What are the strategies for enhancing the effective utilization of ICT facilities in instructional process in secondary schools?

The data presented in table 4 showed that majority of the teachers highly agreed $(28.1 \%-38.6 \%)$ and agreed $(21.1 \%-45.6 \%)$ that all the eight strategies suggested are viable tools for enhancing effective utilization and maintenance of ICT facilities in secondary schools.

\section{Table 4}

Strategies for enhancing effective utilization of ICT facilities in secondary schools

\begin{tabular}{|c|c|c|c|c|c|c|c|c|}
\hline \multirow{2}{*}{ ICT strategies } & \multicolumn{2}{|c|}{ Highly agree } & \multicolumn{2}{|c|}{ Agree } & \multicolumn{2}{|c|}{ Fairly agree } & \multicolumn{2}{|c|}{ Highly disagree } \\
\hline & $n$ & $\%$ & $n$ & $\%$ & $n$ & $\%$ & $n$ & $\%$ \\
\hline Provision of alternative source of electricity supply & 16 & 28.1 & 26 & 45.6 & 8 & 14.0 & 7 & 12.3 \\
\hline $\begin{array}{l}\text { Periodic organization of workshops, seminars and } \\
\text { conferences on ICT }\end{array}$ & 19 & 33.3 & 12 & 21.1 & 17 & 29.8 & 9 & 15.8 \\
\hline $\begin{array}{l}\text { Adequate provision of computer hardware for teachers and } \\
\text { students }\end{array}$ & 22 & 38.6 & 14 & 24.6 & 11 & 19.3 & 10 & 17.5 \\
\hline Training of ICT maintenance personnel in schools & 21 & 37.5 & 15 & 25.8 & 10 & 17.9 & 10 & 17.9 \\
\hline $\begin{array}{l}\text { Institutional partnership with professional and corporate } \\
\text { bodies for technical support }\end{array}$ & 16 & 28.1 & 18 & 31.6 & 12 & 21.1 & 11 & 19.3 \\
\hline $\begin{array}{l}\text { Teachers initiate programs that promote interaction with } \\
\text { students through ICT }\end{array}$ & 19 & 33.3 & 17 & 29.8 & 11 & 19.3 & 10 & 17.5 \\
\hline $\begin{array}{l}\text { School management provides leadership roles for teachers } \\
\text { and students' in the use of ICT }\end{array}$ & 20 & 35.1 & 16 & 28.1 & 11 & 19.3 & 10 & 17.3 \\
\hline $\begin{array}{l}\text { Encourage and support teachers financially to own personal } \\
\text { computer }\end{array}$ & 19 & 33.3 & 15 & 26.3 & 8 & 14.0 & 15 & 26.3 \\
\hline
\end{tabular}

4.5 Relationship in the perception of teachers and students on the extent of utilization of ICT facilities in instructional process in secondary schools

The result presented in table 5 showed that the $r$-value of 0.045 at $p<0.05$ is not significant. The null 
Effective utilization and maintenance of ICT for quality teaching and learning outcome in Nigeria

hypothesis $\left(\mathrm{H}_{\mathrm{o}}\right)$ of no significant relationship is accepted while the alternative hypothesis $\left(\mathrm{H}_{\mathrm{a}}\right)$ is rejected. This indicated that the relationship between teachers and students on the utilization of ICT facilities was low for teaching and learning processes in secondary schools.

\section{Table 5}

Relationship in the perception of teachers and students on the extent of utilization of ICT facilities in instructional process in secondary schools

\begin{tabular}{cccccc}
\hline Items & $n$ & Mean & SD & r & Sig. \\
\hline Utilization of ICT facilities by teachers & 60 & 2.30 & 0.809 & 0.045 & $<0.05$ \\
Utilization of ICT facilities by students & 344 & 2.44 & 0.758 & & \\
\hline
\end{tabular}

\section{Discussions}

The data on the level of availability of ICT facilities in Ondo state public secondary schools for teaching and learning processes showed the following percentage points: very adequate in computer set $(46.7 \%)$, printer $(41.7 \%)$, and bulletin board (31\%); slightly adequate in computer set $(30 \%)$ and bulletin board $(30 \%)$; and inadequate in printer $(35 \%)$, scanner $(54.2 \%)$, internet $(65.5 \%)$, radio $(58.3 \%)$, projector $(56.7 \%)$, telephone (56.7\%), flash drive (46.7\%), CD-ROM (54.2\%), web communication technology (67.8\%), digital camera (51.7\%), and fax machine (75\%). This implies that the provision of ICT facilities is still very low in Ondo State public secondary schools. This is in agreement with the finding of Tella et. al (2007) who reported low availability of ICT facilities in Nigerian secondary schools. The inadequacy of ICT facilities will no doubt put many students at disadvantage in practical application of the procedure involved in learning ICT while teachers would face the challenge of not being able to give most students the desired individual attention to explain difficult concepts to concretize their knowledge and such predicament could narrow the opportunity available to stimulate students for further usage of the ICT facilities for independent learning beyond the normal classroom interaction.

The data on utilization of ICT facilities also revealed low usage in teaching and learning processes in Ondo State Secondary Schools. This implies that teachers and students would have limited opportunities and capability in using ICT facilities to expand their knowledge and skills in curriculum instruction. Consequently the quality of education being given to learners would be inadequate and reflect in low outcome. The hypothesis of no significant relationship was upheld, while the mean score of 2.30 on teachers and the mean score of 2.44 recorded on students implied that both the teachers and the students had similar opinion on the level of utilization of ICT facilities. This further confirmed that both the teachers and students are constrained by inadequate ICT facilities to advance teaching and learning. The major constraints perceived by teachers against effective utilization of ICT facilities for teaching-learning process at secondary school level included inadequate supply of computer hardware and software; irregular power supply; limited training opportunities for teachers; low level of institutional partnership with professional and corporate bodies for technical support; poor funding and maintenance. The principals interviewed said that computer education is at the low ebb, as many of the computer sets are not functioning due to long period of neglect caused by shortage of qualified teachers; and lack of funds to carryout maintenance services. These challenges are inimical to effective teaching and learning processes; consequently, majority of the learners lack the knowledge of ICT in secondary schools,

Strategies such as provision of alternative sources of power supply, capacity building for teachers, and adequate provision of ICT facilities and better management of available ICT facilities were identified as means to improve ICT facilities utilization in secondary schools. This is supported by Ezegwu (2009), and Ugwoke (2011) who found the same strategies as means to ensure effective utilization of ICT in teaching and learning processes. 


\section{Conclusion and recommendation}

The study concluded that ICT is an indispensable tool in fostering curriculum instruction; the inadequacy in the provision of ICT facilities inhibits students' educational opportunities and academic performance. The stakeholders in education sector should be proactive in carrying out periodic needs assessment to determine the gaps in ICT facilities. The strong commitment and collaboration among stakeholders, driven by the unwavering political will of the government and anchored by the Ministry of Education would no doubt strengthen the institutional capacity in the provision and maintenance of ICT facilities, and building teachers' and students' capabilities for effective utilization of ICT facilities in linking teaching to global research networks by sharing ideas with experts in other disciplines; widening their knowledge, skills and experience beyond the scope, structures and limitations of conventional methods that are used in traditional disciplines in curriculum planning and delivery; and achieving better learning outcome in secondary schools.

\section{References:}

Adeyemo, A. A. (2010). The impact of information and communication technology on teaching and learning of physics. International Journal of Educational Research and Technology, 1(2), 6-8.

America Library Association. (1983). The ALA glossary of library and science information. Chicago: ALA Ayeni, A. J. (2010). Teachers' instructional task performance and principals' supervisory roles as correlates of quality assurance in secondary schools in Ondo State. Unpublished doctoral dissertation, Obafemi Awolowo University, Ile-Ife, Nigeria.

British Educational Communication and Technology Agency. (2001). The secondary school of the future: A report to the Department for Education and Employment. Retrieved January 5, 2013, from http://www.becta

Bello-Osagie, K., \& Olugbamila, A. (2009, December 31). Events that shape education. The Nation, p. B2. Ede, E.O. (1999) Hindrances to the implementation of information and communication technologies in the teaching and learning of technical drawing in Nigerian universities; Nigerian Vocational Journal, 14(1), 60-70.

Federal Ministry of Education. (2011a). The state of education in Nigeria: beyond access. Abuja: Federal Inspectorate Services.

Federal Ministry of Education. ( 2011b). Statistics of education in Nigeria: 2006-2010. Abuja: Statistics and NEMIS Branch, Federal Ministry of Education.

Federal Ministry of Education. (2009). Repositioning the Nigerian education sector. Newsletter, 23, 27-28.

Federal Ministry of Education. (2006). Operation reach all secondary schools inspection exercise. Abuja: Federal Ministry of Education Publication.

Federal Republic of Nigeria. (2004). National Policy on Education (4 ${ }^{\text {th }}$ ed.). Lagos: NERDC Press.

Federal Ministry of Education. (2003). Education sector status report. Abuja: Federal Ministry of Education with support from UNESCO/Japan Trust Fund Project.

Hussaain, M. A., Iqbal, M. Z., \& Akhtar, M. S. (2010). Technology based learning environment and student achievement in English as a foreign language in Pakistan. Journal of World Academy of Science, Engineering, and Technology, 61, 129-133.

Mishra, R. C. (2008). Educational research and development. New Delhi: APH Publishing Corporation.

Nurmi . S., \& Jakkola, T. (2005). Problem underlying the learning object approach. International Journal of Instructional Technology and Distance Learning, 2(1), 61-66.

Ogwo, B. A., \& Oranu, R. N. (2006). Methodology in formal and non-formal technical/vocational education. Enugu: IJEJAS Publishing Company.

Okoro, F. N. (2008). Application of ICT in business education instructional methods in Nigeria universities. International Journal of Educational Research, 8, 21-27.

Olulube, N.P., \& Ubogu, A. E. (2009). ICT and distance education. In A Cartelli \& M. Palme (Eds.). Encyclopedia of information and communication technology (pp. 396-400). USA: Information Science 
Reference.

Ondo State Ministry of Education. (2012). Analysis of academic achievement in West African senior school certificate examinations. Akure: Department of Planning, Research and Statistics.

Owadiae, I. (2012, August 11). West African Senior School Certificate Examination results. The Punch, p. 8.

Owadiae, I. (2011, August 11). West African Senior School Certificate Examination results. The Nation, p 4.

Owadiae, I. (2010, August 31). West African Senior School Certificate Examination results. The Punch, p 39.

Quality Education Assurance Agency. (2010). Analysis of results of WAEC/NECO senior secondary school certificate examinations. Akure: Department of Planning, Research and Statistics.

Tella, A., Tella, A., Toyobo O. M., Adika L. O., \& Adeyinka, A. A. (2007). An assessment of secondary school teachers uses of ICTs: Implications for further Development of ICT's use in Nigerian secondary school. Turkish online Journal of Educational Technology, 6(3), 5-16.

Ugwoke, E. O. (2011). Effective utilization of ICT for repositioning business education program in tertiary institutions in Nigeria for national development International Journal of Education Research, 11(1), 202-214.

Yusuf, M. O., \& Onasanya, S. A. (2004). Information and communication technology (ICT) and teaching in tertiary institutions (pp. 67-76). Retrieved January 5, 2013, from http://unilorin.edu.ng/publications/onasanya/ICT\%20AND\%20TEACHING\%20IN\%20TERTIARY\%2 OINSTITUTIONS.pdf 
Ayeni, A. J. \& Ogunbameru, M. 